EESTI NSV TEADUSTE AKADEEMIA TOIMETISED 1955. IV kd., nr. 3 ИЗВЕСТИЯ АКАДЕМИИ НАУК ЭСТОНСКОИ ССР 1955. Том IV, № 3

\title{
КОЛЕБАНИЕ И ИЗМЕНЧИВОСТЬ ГОДОВОГО СТОКА РЕК ЭСТОНСКОЙ ССР
}

\author{
B. А. ИОНАТ, \\ кандидат технических наук
}

При -производстве гидрологических расчетов обычно требуется определение размера годового стока, отвечающего заданной обеспеченности. Так, например, при проектировании водоснабжения за расчетную обеспеченность, как правило, принимают 90-99\%, для рыбного хозяйства $85-90 \%$, для энергетики $-50-75 \%$ и т: д.

Нѐобходимость получения расчетных характеристик заданной обеспеченности требует детального изучения речного стока в течение длительного периода и установления вероятных размеров амплитуды его колебания. Решение вопроса о размерах годового стока заданной обеспеченности может быть произведено при наличии достаточно продолжительных измерений (20-40 лет) путем построения эмпирических кривых обеспеченности или, в случаё отсутствия продолжительных наблюдений, путем построения кривых обеспеченности методами вариационной статистики, дающих меньшую точность.

Как указывает проф. А. В. Огиевский $\left({ }^{2}\right)$, «конечной целью изучения режима стока является установление вероятных колебаний его для нужд водохозяйственных расчетов и проектирования сооружений. Намечаемое использование водных потоков всегда основывается на предположениях о том возможном будущем режиме этих потоков, которого следует ожидать после постройки тех или иных сооружений».

В настоящей работе мы рассматриваем колебания и изменчивость годового стока рек Эстонской ССР

\section{1. Исходные материалы и их оценка}

Исследование изменчивости годового стока рек Эстонской ССР проводится на основании материалов гидрометрических измерений, осуществляемых в сети Управления гидрометеорологической службы ЭССР и дающих наиболее надежные-данные для гидрологических расчетов. Для вычисления коэффициентов вариации используются ряды наблюдений с продолжительностью, превышающей 20 лет. При среднем значении $C_{v}=$ 0,35 средняя квадратичная ошибка коэффициента вариации при $n=20$ лет с учетом асимметричности рядов равна по С. Н. Крицкому и М. Ф. Менкелю (1)

$$
{ }^{\sigma_{C}}=C_{v} \sqrt{\frac{1+3 C_{v}^{2}}{2(n-1)}}=0,35 \sqrt{\frac{1+3 \cdot 0,35^{2}}{2.19}}=0,19 C_{v}
$$

Относительная ошибка составит, таким образом, около $19 \%$. 
Как указывает Д. Л. Соколовский $\left({ }^{3}\right)$, «действительные средние ошибки коэффициента изменчивости близки к теоретическим и даже несколько ниже, что объясняется близостью распределения коэффициентов изменчивости к нормальному, особенно при невысоких значениях последних». Так, Д. Л. Соколовским установлено, что для рек Волхова, Днепра и Западной Двины ошибка при вычислении $C_{v}$ за десятилетний период составила всего $12-19 \%$ при теоретическом ее значении $26-27 \%$. Данное обстоятельство дает нам основание считать, что при вычислении коэффициентов вариации для рек Эстонской ССР, имеющих 20-летние ряды измерений, ошибка определения $C_{v}$ составит не более $12-15 \%$, т. е. вычисления будут производиться с достаточной для практики точностью. Наконец, принимая во внимание еще и то, что некоторые ряды имеют продолжительность бо́льшую, чем 20 лет, можно считать, что в среднем ошибка при вычислении $C_{v}$ для всех рассматриваемых рек составит около $10 \%$.

Наиболее полно в гидрометрическом отношении освещены следующие реки Эстонской ССР (табл. 1).

Таблица 1

\begin{tabular}{l|l|c|c}
\hline Река & Створ & $\begin{array}{c}\text { Площадь } \\
\text { водосбора } \\
\text { км² }^{2}\end{array}$ & $\begin{array}{c}\text { Число пол- } \\
\text { ных лет } \\
\text { наблюдений }\end{array}$ \\
\hline & & & 38 \\
Нарва & Васкнарва & 47800 & 27 \\
Пуртсе & Люганусе & 792 & 22 \\
Кейла & Урба & 663 & 26 \\
Лейва & Кейла & 84,3 & 28 \\
В. Эмайыги & Паюба & 1070 & 34 \\
С. Эмайыги & Тыллисте & 7850 & 26 \\
Выханду & Тарту & 853 & 20 \\
Педья & Химмисте & 792 & 29 \\
Пярну & Тырве & 5180 & \\
& Орекюла & & \\
& & &
\end{tabular}

Кроме того, имеются наблюдения на реках Ягала -14 лет, Пирита - 16 и Вихтерпалу - 19 лет. Таким образом, непосредственное вычисление $C_{v}$ возможно только для ограниченного числа рек.

\section{2. Многолетний ход годового стока}

Имеющиеся на 1 января 1953 года материалы гидрометрических измерений позволяют в первом приближении составить картину хода и колебаний годового стока, так как включают в свой состав как многоводные так и маловодные годы. Ход стока за последние 25-30 лет, в течение которых велись более или менее систематические гидрологические наблюдения, хорошо выражен на графиках изменения средних модулей стока по годам (рис. $1,2,3,4)$. К сожалению, ряды наблюдений имеют разрывы, обусловленные отсутствием данных за период военных действий и падаюшие в основном на 1943-1945 годы.

При рассмотрении многолетнего хода стока обращает на себя внимание чрезвычайная маловодность периода с 1936 по 1941 год. Начавшееся с 1935 года поннжение водности достигло своего предела в 1939 1940 годах. Так, в 1939 году среднегодовое значение стока составило только 0,46 нормы для реки Кейла, 0,44 для реки Васалемма и 0,39 для реки Пярну. В 1940 году особая маловодность отмечена на реках Педья и Нарва (сток реки Педья составил 0,64 , а реки Нарва $-0,48$ от нормы). 
В рассматриваемый период только 1936 год, да и то не по всем рекам, дал значения стока, приближающиеся к норме. На р. Пярну не было ни одного года, равного по водности среднему или близко приближавшемуся к нему. Средний сток за 1936-1941 годы на реках бассейна Финского

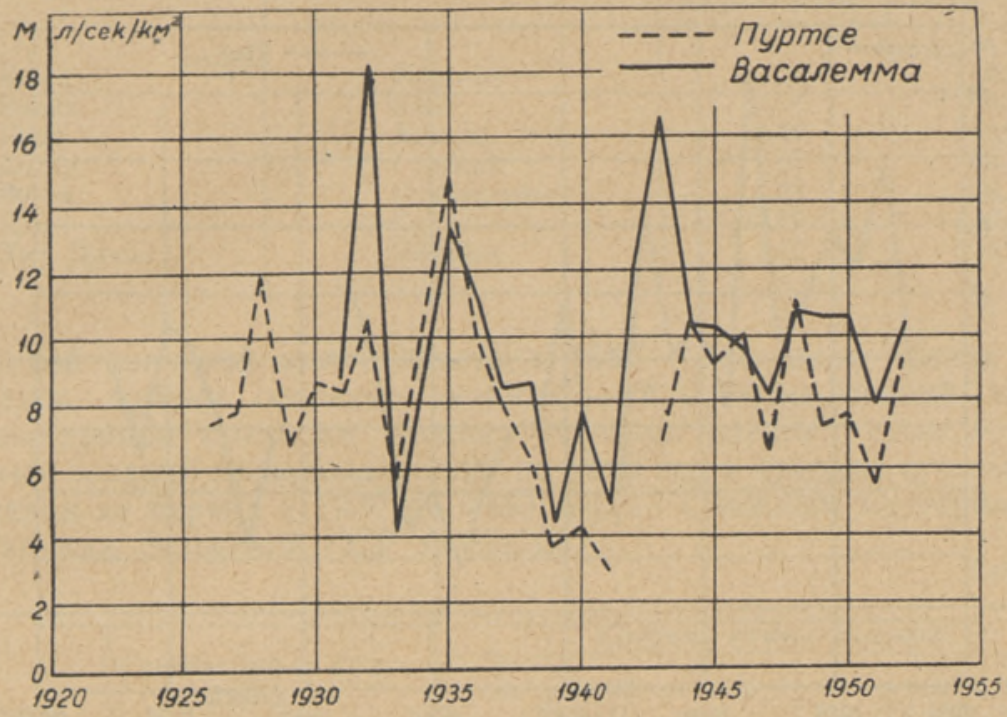

Рис. 1.

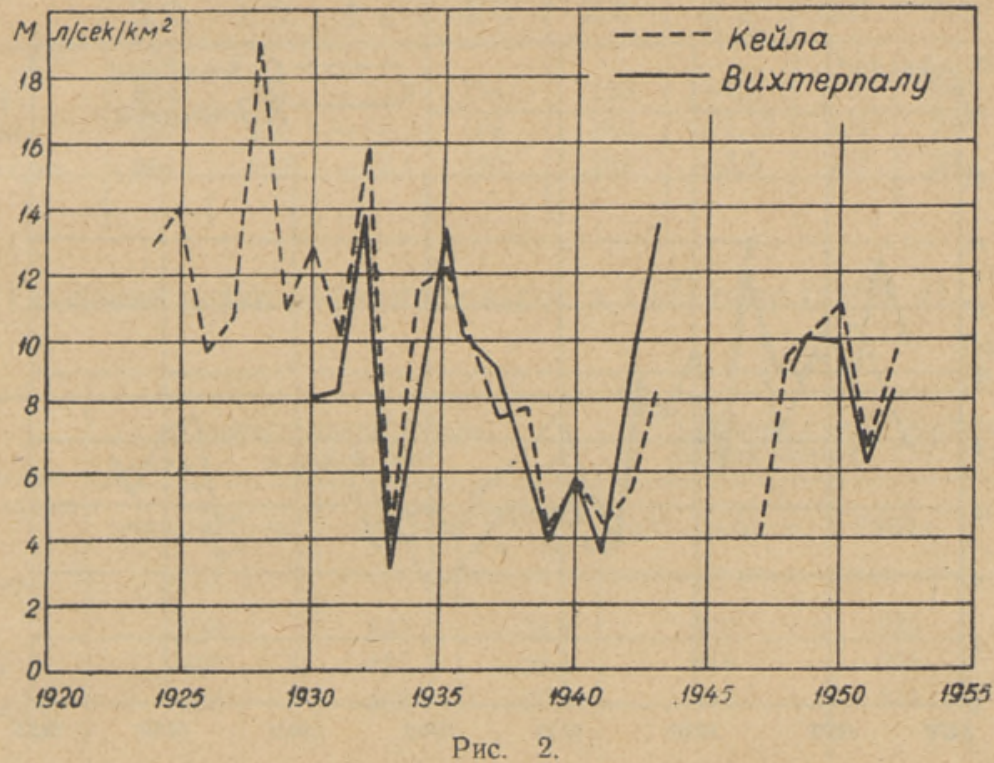

залива составил, соответственно, для реки Пуртсе 0,72 , для р. Васалемма 0,77 , p. Кейла 0,70 от среднего многолетнего стока, а дефицит стока за этот период составил в среднем 1,62 годовых объема стока.

Для реки Пярну средняя величина годового стока за эти годы была еще меньше и равнялась лишь 0,64 от средней многолетней величины, а дефицит стока за период составил, соответственно, 2,16 годовых 
объема. У реки Суур Эмайыги дефицит стока за рассматриваемый промежуток времени составил 1,92 годовых объема стока. Маловодность 1936-1941 годов не являлась региональным явлением, характерным лишь для территории Эстонской ССР. Қак указывает Д. Л. Соколов-

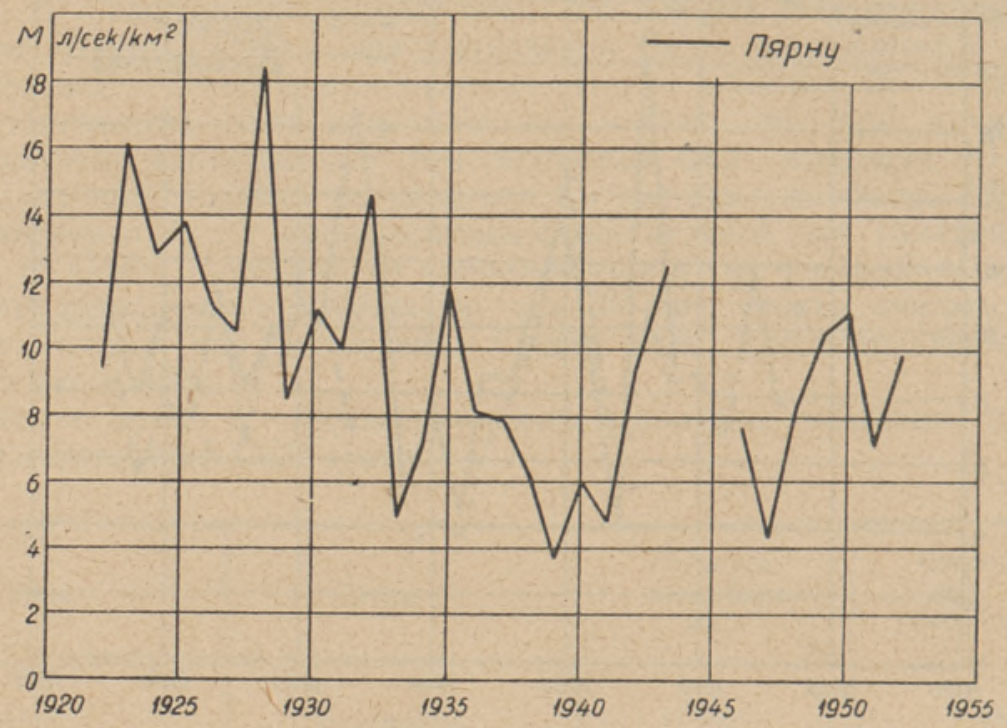

Рнс. 3.

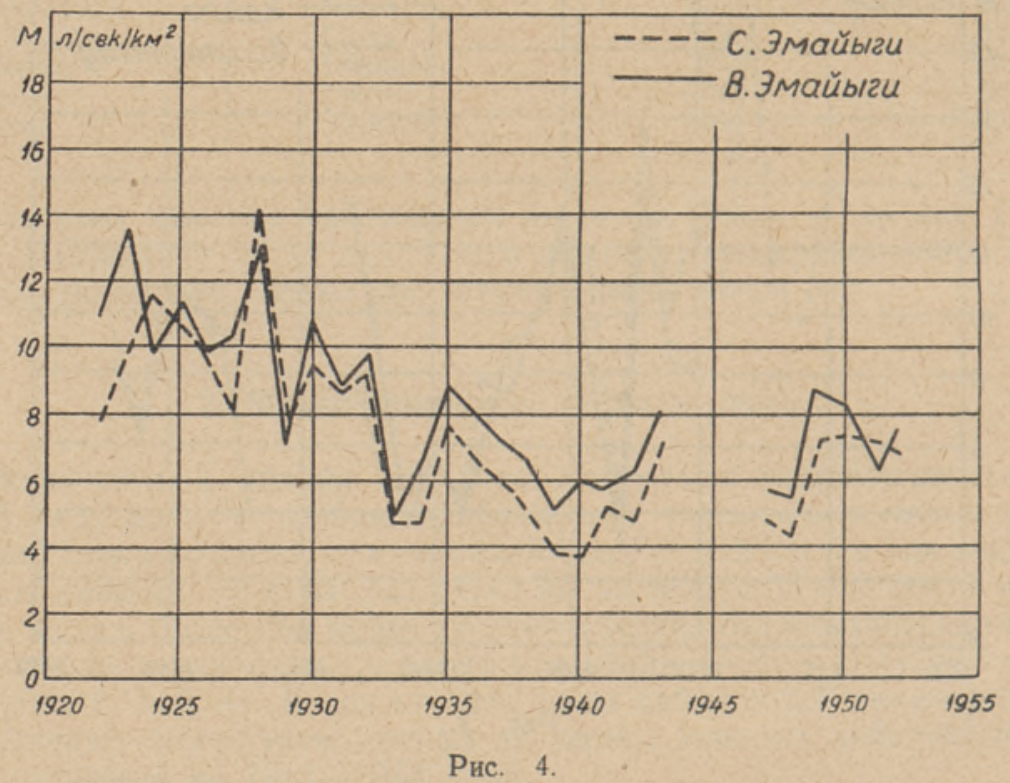

ский $\left({ }^{4}\right)$, депрессия $1930-1940$ годов захватила и удаленные от Эстонской ССР районы Урала, бассейны рек Волги и Дона и северную часть Белорусси. Для иллюстрации распределения водности периода с 1923 по 1929 и с 1930 по 1940 годы приводим данные по указанным выше районам, заимствованные у Д. Л. Соколовского. 


\begin{tabular}{c|l|c|c}
\hline Река & Пункт & \multicolumn{2}{|c}{$\begin{array}{c}\text { Oтношение к среднему } \\
\text { многолетнему расходу }\end{array}$} \\
\hline & & $1923-1929$ гг. & $1930-1940$ гг. \\
\hline Кама & Молотов & 1,23 & 0,82 \\
Белая & Уфа & 1,18 & 0,69 \\
Урал & Кушум & 1,20 & 0,64 \\
Волга & Горький & 1,07 & 0.86 \\
Волга & Сталинград & 1,09 & 0,78 \\
Дон & Калач & 1,12 & 0,80 \\
Зап. Двина & Витебск & & 0,91 \\
& &
\end{tabular}

Основной причиной маловодности в 1936-1941 годах явился дефицит осадков, причем особенно значительный в летне-осенний период. Для иллюстрации приводим средние значения средних сумм годовых и сезонных осадков за период с 1920 по 1940 год и средние суммы годовых осадков за период с 1936 по 1940 год по основным метеорологическим станциям Эстонской ССР (табл. 3).

Таблица 3

\begin{tabular}{|c|c|c|c|c|c|c|c|c|c|}
\hline \multirow{3}{*}{$\begin{array}{c}\text { Метеороло- } \\
\text { гическая } \\
\text { станция }\end{array}$} & \multirow{2}{*}{\multicolumn{3}{|c|}{$\begin{array}{c}\text { Среднегодовая сумма } \\
\text { осадков, мм }\end{array}$}} & \multicolumn{6}{|c|}{ Средняя сумма осадков } \\
\hline & & & & \multicolumn{3}{|c|}{$\begin{array}{l}\text { за зимний период } \\
\text { (XI-III), мм }\end{array}$} & \multicolumn{3}{|c|}{$\begin{array}{l}\text { за летний период } \\
\text { (IV-X), мм }\end{array}$} \\
\hline & $\begin{array}{l}1: \dot{4} \\
\text { 웡유 }\end{array}$ & 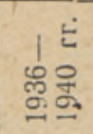 & 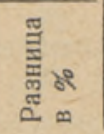 & $\begin{array}{l}1: \\
\text { 유유 }\end{array}$ & 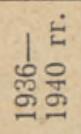 & 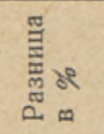 & $\begin{array}{l}\text { 杗 } \\
\text { 웡 }\end{array}$ & 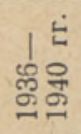 & 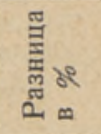 \\
\hline Пярну & 564 & 495 & $-12,2$ & 154 & 155 & $+0,6$ & 410 & 340 & $-17,1$ \\
\hline Таллин & 597 & 560 & $-6,2$ & 178 & 180 & $+1,12$ & 419 & 340 & $-18,8$ \\
\hline Васкнарва & 668 & 580 & $-13,1$ & 195 & 188 & $-3,6$ & 473 & 392 & $-17,1$ \\
\hline
\end{tabular}

Особенно велик дефицит осадков в 1939 году (табл. 4).

Таблица 4

\begin{tabular}{|c|c|c|c|c|c|c|}
\hline \multirow{2}{*}{$\begin{array}{l}\text { Метеорологи- } \\
\text { ческая станция }\end{array}$} & \multicolumn{3}{|c|}{$\begin{array}{c}\text { Среднегодовая сумма } \\
\text { осадков, мм }\end{array}$} & \multicolumn{3}{|c|}{$\begin{array}{l}\text { Средняя сумма осадков за } \\
\text { летний период (IV-X), мм }\end{array}$} \\
\hline & $1920-1940 \mathrm{rr}$. & 1939 r. & $\begin{array}{l}\text { Разница } \\
\text { в \% }\end{array}$ & $1920-1940 \mathrm{rr}$. & $1939 \mathrm{r}$. & $\begin{array}{l}\text { Разница } \\
\text { в \% }\end{array}$ \\
\hline $\begin{array}{l}\text { Пярну } \\
\text { Таллин } \\
\text { Васкнарва }\end{array}$ & $\begin{array}{l}564 \\
597 \\
668\end{array}$ & $\begin{array}{l}343 \\
421 \\
452\end{array}$ & $\begin{array}{l}-39,2 \\
-29,4 \\
-32,4\end{array}$ & $\begin{array}{l}410 \\
419 \\
473\end{array}$ & $\begin{array}{l}225 \\
294 \\
274\end{array}$ & $\begin{array}{r}-45,0 \\
-29,9 \\
-42,0\end{array}$ \\
\hline
\end{tabular}

Приведенные данные показывают, что водность рек Эстонской ССР в значительной мере определяется размером осадков летнего периода. Значительный дефицит осадков за этот период (например, в 1939 году) ведет не только к снижению расходов- рек в текущем году, но и в значительной мере снижает сток зимних месяцев следующего года вследствие резкого уменьшения запаса грунтовых вод.

С другой стороны, обильные дождевые осадки (например, в 1923, 
1928 и 1935 годах) обусловливают повышение водности рек в указанные годы и в зимний период следующих за ними лет.

Абсолютные значения амплитуды колебания стока за период наблюде-

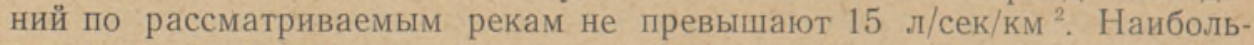
шие размеры модуля годового стока зарегистрированы на реке Кейла в 1928 году - 19,1 л/сек/км ${ }^{2}$. Наименьший модуль стока $\left(2,7\right.$ л/сек/км $\left.{ }^{2}\right)$ имела река Пуртсе в 1941 году. Равномерность годового стока можно в первом приближении определить размером отношения $\tau=\frac{M_{\max }}{M_{\min }}$.

Размер $\tau$ для различных рек Эстонской ССР приводится в таблице 5.

Таблица 5

\begin{tabular}{l|l|r|r|r|r|r}
\hline \multicolumn{1}{c|}{ Река } & Створ & $\begin{array}{c}\text { Площадь } \\
\text { водосбора } \\
\text { км}^{2}\end{array}$ & $\begin{array}{c}\text { Число лет } \\
\text { наблюде- } \\
\text { ния̆ }\end{array}$ & $M_{\max }$ & $M_{\min }$ & $\tau=\frac{M_{\max }}{M_{\text {min }}}$ \\
\hline Нарва & Васкнарва & 47800 & 38 & 13,6 & 3,4 & 4,0 \\
Пуртсе & Люганусе & 792 & 27 & 14,9 & 2,7 & 5,5 \\
Ягала & Линнамяэ & 1582 & 14 & 13,9 & 3,5 & 4,0 \\
Пирита & Лагеди & 675 & 15 & 16,7 & 3,3 & 5,1 \\
Кейла & Кейла & 665 & 26 & 19,1 & 4,0 & 4,8 \\
Васалемма & Урба & 383 & 22 & 18,2 & 4,0 & 4,6 \\
Вихтерпалу & Энглема & 468 & 19 & 13,8 & 3,1 & 4,5 \\
Пярну & Орекюла & 5180 & 29 & 18,4 & 3,7 & 5,0 \\
В. Эмайыги & Тыллисте & 1070 & 28 & 13,6 & 4,9 & 2,8 \\
С. Эмайыги & Тарту & 7850 & 34 & 14,3 & 3,8 & 3,8 \\
Выханду & Химмисте & 853 & 26 & 14,1 & 5,1 & 2,8 \\
Педья & Тырве & 792 & 20 & 10,5 & 3,7 & 2,8 \\
Лейва & Паюба & 84,3 & 23 & 15,3 & 4,2 & 3,7 \\
& & & & & &
\end{tabular}

Данные таблицы 5 не могут служить точным критерием зарегулированности стока, так как они относятся к створам, имеющим различные размеры водосборной площади, различную продолжительность наблюдений и т. д. Однако они в основном правильно отражают картину зарегулированности стока, давая меньшие значения г для зарегулированных озерами и имеющих лучшее грунтовое питание рек бассейна Чудского озера и повышенное значение для слабо ззарегулированных рек западной части бассейна Финского и Рижского заливов.

\section{Изменчивость годового стока}

Ряды распределения годового стока лучше всего характеризуются параметрами кривых распределения - коэффициентами вариации и асимметрии. Қак указывалось выше, имеющийся в наличии материал гидрометрических измерений дает возможность вычисления коэффициентов вариации с точностью порядка $10-15 \%$. Непосредственное вычисление же коэффициентов асимметрии методами вариационной статистики при длине рядов в 20-25 лет дает слишком большие ошибки и не может быть рекомендовано. Действительно, ошибка вычисления $C_{s}$ по формуле, предложенной С. Н. Крицким и $M$. $Ф$. Менкелем ( $\left.{ }^{1}\right)$, при $n=20$ лет составит при $C_{v}=0,35$ и $C_{s}=2 C_{v}=0,70$

$$
{ }^{\circ} C_{s}=\sqrt{\frac{6}{n}\left(1+6 C_{v}^{2}+5 C_{v}^{4}\right)}=\sqrt{0,543}=0,74,
$$

или относительная ошибка

$$
\frac{{ }^{\circ} C_{s}}{C_{s}}=\frac{0,74}{0,70}=1,06=106 \% \text {. }
$$


Таким образом, ошибки вычисления $C_{s}$ весьма велики, и $C_{s}$ необходимо отыскивать иным способом.

Принимая во внимание указанное обстоятельство, нами для вычисления $C_{s}$ применена формула С. Н. Крицкого и $М$. Ф. Менкеля, согласно которой для асимметричной биномиальной кривой

$$
C_{s}=\frac{2 C_{v}}{1-K_{\min }}
$$

Вычисленные значения $C_{v}$ и $C_{s}$ приводятся в таблице 6.

Таблица 6

\begin{tabular}{l|l|c|c|c|c|c|c}
\hline \multicolumn{1}{c|}{ Река } & Створ & $\begin{array}{c}\text { Число } \\
\text { лет на6- } \\
\text { люденин }\end{array}$ & $C_{v}$ & $\sigma_{C_{v}}$ & $K_{\min }$ & $C_{s}$ & $\frac{C_{s}}{C_{v}}$ \\
\hline Нарва & Васкнарва & 38 & 0,326 & 0,044 & 0,470 & 1,230 & 3,77 \\
Пуртсе & Люганусе & 27 & 0,331 & 0,052 & 0,318 & 0,971 & 2,93 \\
Лейва & Паюба & 23 & 0,364 & 0,064 & 0,480 & 1,400 & 3,85 \\
Кейла & Кейла & 26 & 0,390 & 0,066 & 0,417 & 1,338 & 3,43 \\
Васалемма & Урба & 22 & 0,350 & 0,063 & 0,409 & 1,185 & 3,39 \\
Пярну & Орекюла & 29 & 0,370 & 0,058 & 0,386 & 1,206 & 3,26 \\
В. Эмайыги & Тыллисте & 28 & 0,294 & 0,045 & 0,598 & 1,463 & 4,98 \\
С. Эмайыги & Тарту & 34 & 0,336 & 0,046 & 0,506 & 1,361 & 4,05 \\
Выханду & Химмисте & 26 & 0,266 & 0,041 & 0,644 & 1,495 & 5,62 \\
Педья & Тырве & 20 & 0,255 & 0,045 & 0,500 & 1,024 & 4,00 \\
& & & & & & &
\end{tabular}

Данные таблицы 6 показывают, что при вычислении $C_{s}$ по формуле Менкеля-Крицкого для рек Эстонской ССР получается значение $C_{s}$ большее, чем $2 C_{v}$, причем в некоторых случаях в $2-2,5$ раза. Применение зависимости $C_{s}=2 C_{v}$ для случаев, когда на деле $C_{s}>2 C_{v}$, дает несколько преуменьшенное значение модульных коэффициентов для обеспеченностей $0,1-10 \%$ и $90-99,9 \%$. Так, например, принимая для реки Пярну $C_{s}=2 C_{v}=0,74$, вместо 1,206 , получим для расхода обеспеченности $0,1 \%$ при $C_{v}=0,37:$ a) при $C_{s}=1,206 \mathrm{~K}=1+0,37 \cdot 4,82=2,78$; б) при $C_{s}=0,74 K=1+0,37 \cdot 4,16=2,54$.

Таким образом, расчетный расход обеспеченности $0,1 \%$ был бы ниже действительного на $8,6 \%$.

Для проверки совпадения эмпирических кривых с теоретическими кривыми при принятых округленно значениях $C_{s}=2 C_{v}, 4 C_{v}$ и $5 C_{v}$ произведена накладка эмпирических и теоретических кривых (рис. 5, 6, $7,8)$, причем обеспеченность расходов определялась по формуле

$$
p=\frac{m}{n+1} 100 \text {. }
$$

Применение довольно распространенной, так называемой американской формулы

$$
p=\frac{m-0,5}{n} 100
$$

не рекомендуется, так как эта формула, как указывает А. В. Огиевский $\left({ }^{2}\right)$, дает для первого члена убывающего ряда повторяемость, равную $2 n$, что явно не отвечает действительности.

Рассмотрение эмпирических кривых обеспеченности и кривых, построенных по отношениям $C_{s}=2 C_{v}, C_{s}=4 C_{v}$ и $C_{s}=5 C_{v}$ показывает, что эмпирическая кривая дает расхождение с теоретическими кривыми, особенно заметное на концах кривых в зонах с обеспеченностью $0,1-10 \%$ 
и $90-99,9 \%$. Значения $C_{s}$, вычисленные по формуле Менкеля-Крицкого, дают кривые, наиболее приближающиеся к эмпирическим в зоне расходов с обеспеченностью $0,1-10 \%$, зато в зоне с обеспеченностью расходов $90-99,9 \%$ кривые дают значительное $(15-20 \%)$ завышение модульных коэффициентов. Кривые $C_{s}=2 C_{v}$ дают несколько большее

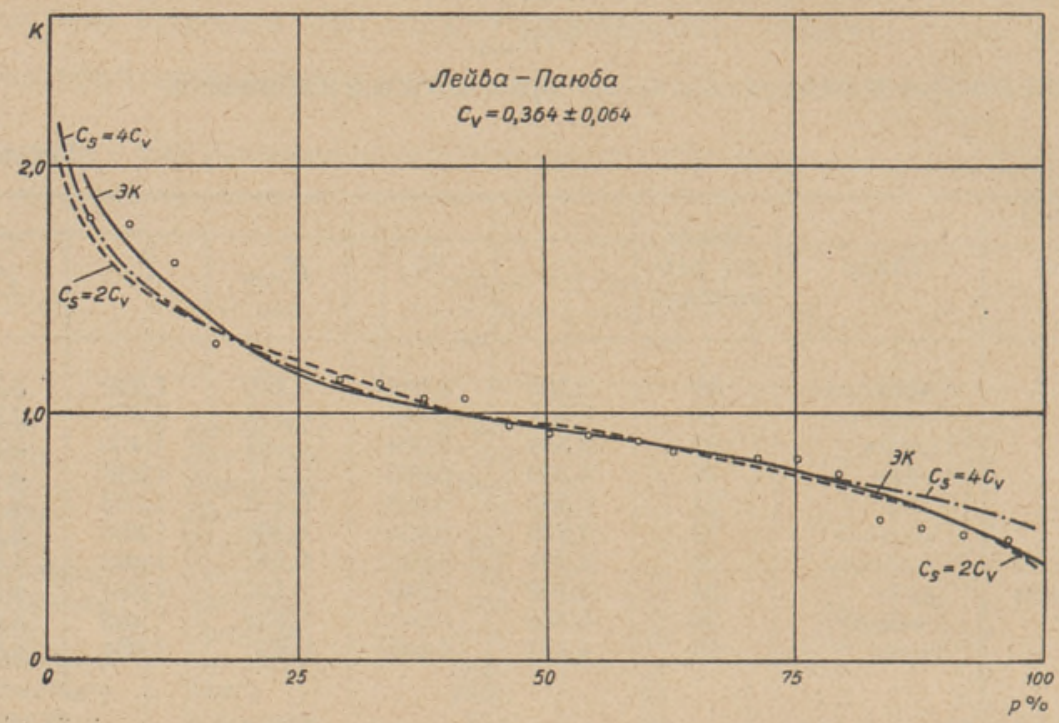

Рис. 5.

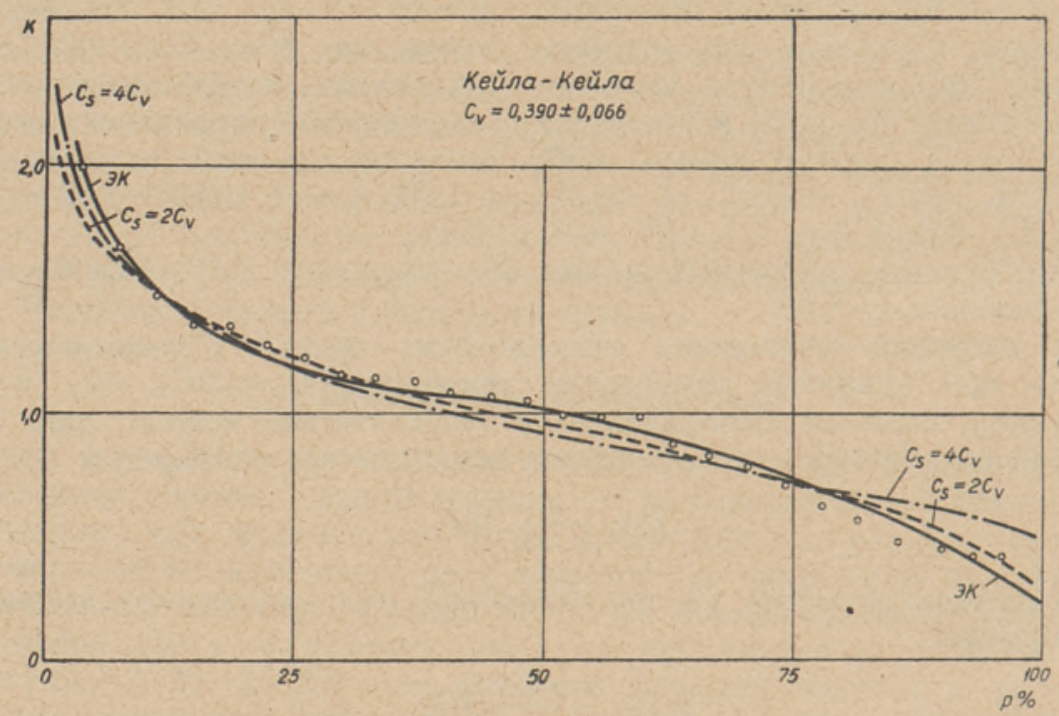

Рис: 6.

расхождение в зоне расходов с обеспеченностью $0,1-10 \%$ и более близкие значения в зоне расходов с обеспеченностью 90-99,9\%.

Так как размеры среднегодового стока в зоне максимумов $(0,1-10 \%)$ особого практического значения для гидрологических расчетов не имеют, a расходы с обеспеченностью $80-99,9 \%$, наоборот, имеют весьма важное значение для энергетики, водоснабжения и рыбного хозяйства, то 
можно рекомендовать при производстве расчетов в этом случае применение кривой $C_{s}=2 C_{v}$. Для расходов с обеспеченностью $10-80 \%$ эмпирическая кривая не дает значительных расхождений с кривыми, построенными по соотношению $C_{s}=2 C_{v}, 4 C_{v}$ и $5 C_{v}$. Таким образом, можно рекомендовать при производстве гидрологических расчетов принимать для всех рек Эстонской ССР $C_{s}=2 C_{v}$.

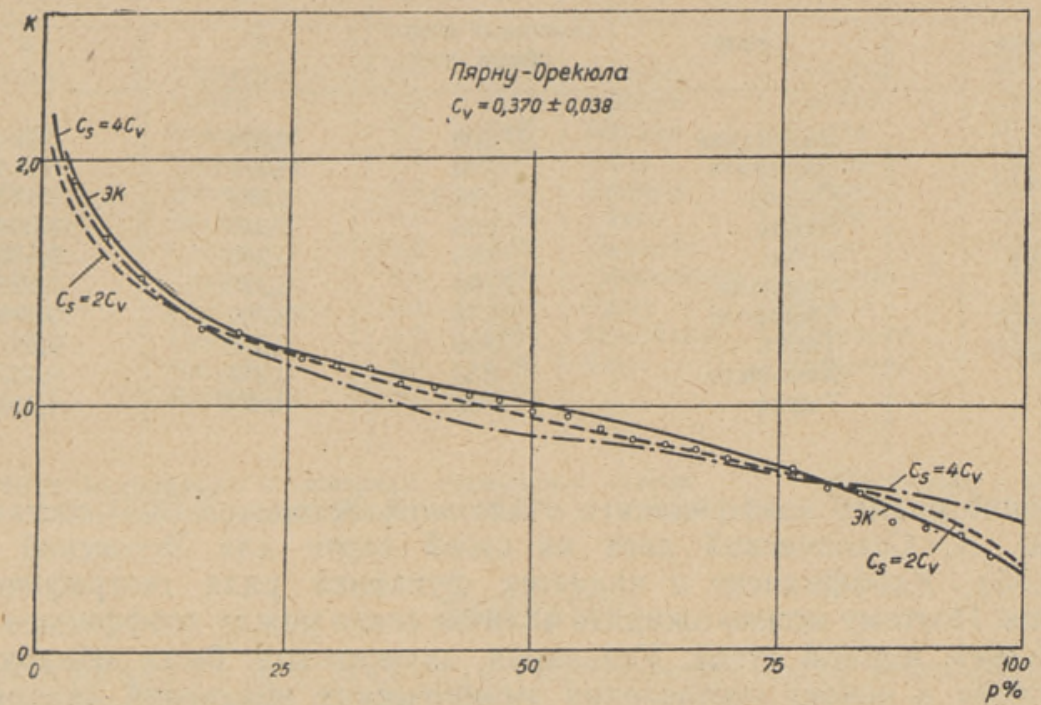

Рнс. 7.

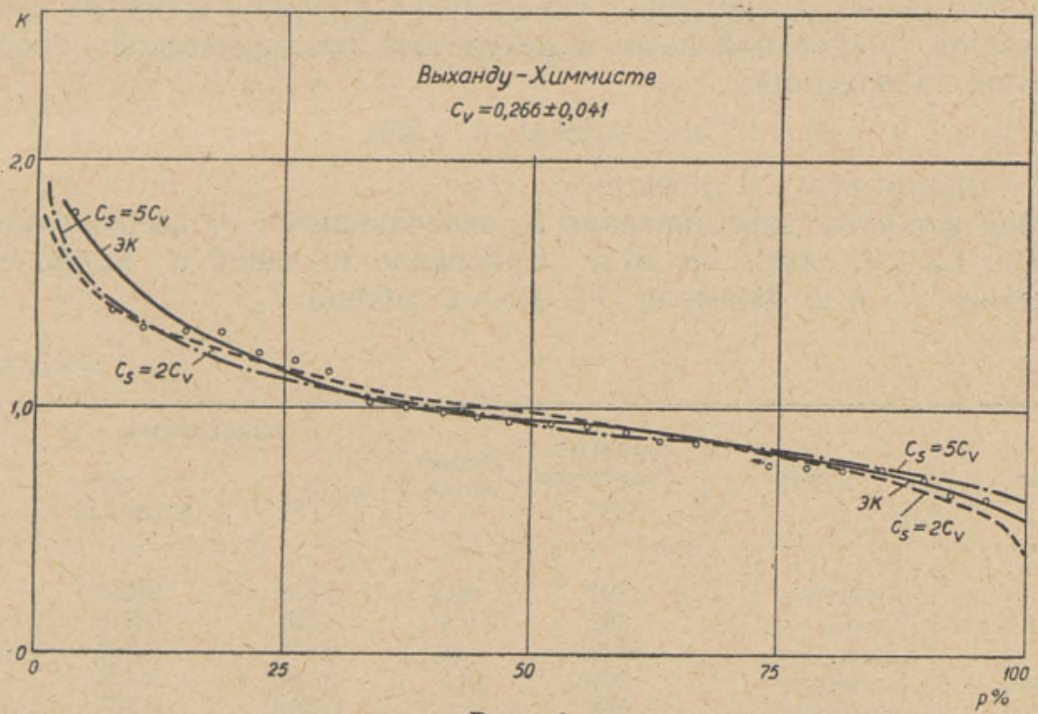

Рис. 8.

Для неисследованных рек Д. Л. Соколовский рекомендует определять коэффициент вариации $C_{v}$ по формуле:

$$
C_{v}=a-0,063 \lg (F+1),
$$

где $a$ - географический параметр, выражающий зависимость $C_{v}$ от зональных ландшафтных условий; $F$ - площадь бассейна в км². 
Значение параметра $a$ для Эстонской ССР может быть определено на основании значений $C_{v}$, вычисленных для рек с продолжительными рядами гидрометрических измерений. Значения $a$, вычисленные по величине $C_{v}$ для отдельных бассейнов рек Эстонской ССР, приводятся в таблице 7.

Таблица 7

\begin{tabular}{l|l|c|c|c}
\hline \multicolumn{1}{c|}{ Река } & Створ & $\begin{array}{r}\text { Площадь водо- } \\
\text { сбора км² }\end{array}$ & $C$ & $a$ \\
\hline Нарва & Васкнарва & 47800 & 0,326 & 0,621 \\
Пуртсе & Люганусе & 792 & 0,331 & 0,514 \\
Лейва & Паюба & 84,3 & 0,364 & 0,485 \\
Кейла & Кейла & 665 & 0,390 & 0,568 \\
Васалемма & Урба & 383 & 0,350 & 0,513 \\
Пярну & Орекюла & 5180 & 0,370 & 0,603 \\
В. Эмайыги & Тыллисте & 1070 & 0,294 & 0,485 \\
С. Эмайыги & Тарту & 7850 & 0,336 & 0,581 \\
Выханду & Химмисте & 853 & 0,266 & 0,450 \\
Педья & Тырве & 792 & 0,256 & 0,440 \\
& & & &
\end{tabular}

Средний размер коэффициента $a$ для всей Эстонской ССР составляет 0,54 (Д. Л. Соколовский дает на своей карте для Эстонской ССР $a=0,55)$. Коэффициент $a$ является функцией ряда географических факторов. Поэтому можно ожидать наличие связи между коэффициентом $a$ и, например, нормой стока. Указанная зависимость была обнаружена и положена в основу составления эмпирических уравнений (например, формулы Шевелева), применяемых для определения значений $C_{v}$ по величине нормы стока.

Для безозерных рек Эстонии определение $a$ можно вести по следующей формуле, полученной нами в результате статистической обработки материалов наблюдений:

$$
a=0,05\left(M_{0}+1,35\right)
$$

где $M_{0}$ - норма стока в л/сек/км².

Данная формула дает значения $a$, отличающиеся от вычисленных по значениям $C_{v}$ в среднем на $10 \%$. Сравнение значений $a$, вычисленных по значениям $C_{v}$ и по формуле (1), дано в таблице 8.

Таблица 8

\begin{tabular}{|c|c|c|c|c|c|c|}
\hline \multirow[b]{2}{*}{ Река } & \multirow[b]{2}{*}{ Створ } & \multirow{2}{*}{$\begin{array}{c}\text { Площадь } \\
\text { водосбора } \\
\text { км² }^{2}\end{array}$} & \multirow[b]{2}{*}{$\begin{array}{l}\text { Норма } \\
\text { стока }\end{array}$} & \multicolumn{2}{|c|}{$a$ вычисленное } & \multirow{2}{*}{$\begin{array}{l}\text { Рас- } \\
\text { хожде- } \\
\text { ние } \\
\text { в \% }\end{array}$} \\
\hline & & & & по $C_{v}$ & $\begin{array}{l}\text { по фор- } \\
\text { муле (1) }\end{array}$ & \\
\hline $\begin{array}{l}\text { Пуртсе } \\
\text { Кейла } \\
\text { Пярну } \\
\text { В. Эмайыги } \\
\text { Выханду } \\
\text { Педья }\end{array}$ & $\begin{array}{l}\text { Люганусе } \\
\text { Кейла } \\
\text { Орекюла } \\
\text { Тыллисте } \\
\text { Химмисте } \\
\text { Тырве }\end{array}$ & $\begin{array}{r}792 \\
665 \\
5180 \\
1070 \\
853 \\
792\end{array}$ & $\begin{array}{l}8,2 \\
9,4 \\
9,6 \\
8,2 \\
7,9 \\
7,4\end{array}$ & $\begin{array}{l}0,514 \\
0,568 \\
0,603 \\
0,485 \\
0,450 \\
0,440\end{array}$ & $\begin{array}{l}0,480 \\
0,538 \\
0,550 \\
0,475 \\
0,465 \\
0,438\end{array}$ & $\begin{array}{l}-6,5 \\
-5,0 \\
-8,5 \\
-2,0 \\
+3,0 \\
-0,5\end{array}$ \\
\hline
\end{tabular}

Таким образом, формула (1) дает возможность довольно точно вычислить значение $a$, если известна норма стока данной реки. Подставив значение $a$ в формулу Д. Л. Соколовского, получим формулу для определения коэффициента вариации годового стока рек Эстонской ССР:

$$
C_{v}=0,05\left(M_{0}+1,35\right)-0,063 \lg (F+1) .
$$


Для уточнения параметра $a$ по территории Эстонской ССР можно воспользоваться значениями $a$, вычисленными по формуле (1) и приведенными в таблице 9.

Таблица 9

\begin{tabular}{|c|c|c|c|c|c|c|c|}
\hline Река & Створ & $M_{0}$ & $a$ & Река & Створ & $M_{0}$ & $a$ \\
\hline $\begin{array}{l}\text { Пюхайыги } \\
\text { Сельге } \\
\text { Валге } \\
\text { Ягала } \\
\text { Пирита } \\
\text { Вихтерпалу } \\
\text { Раудна } \\
\text { Рейю } \\
\text { Паадремаа } \\
\text { Ыхне } \\
\text { Эльва } \\
\text { Пунапеа }\end{array}$ & $\begin{array}{l}\text { Пюхайые } \\
\text { Аркна } \\
\text { Ванакюла } \\
\text { Лнннамяэ } \\
\text { Лагеди } \\
\text { Энглема } \\
\text { Солгути } \\
\text { Сурью } \\
\text { Мытсусилла } \\
\text { Тырва } \\
\text { Эльва } \\
\text { Метскюла }\end{array}$ & $\begin{array}{r}8,9 \\
8,3 \\
9,7 \\
7,6 \\
9,8 \\
9,6 \\
10,2 \\
8,6 \\
10,8 \\
9,0 \\
8,3 \\
9,6\end{array}$ & $\begin{array}{l}0,51 \\
0,48 \\
0,55 \\
0,45 \\
0,55 \\
0,55 \\
0,58 \\
0,50 \\
0,61 \\
0,52 \\
0,48 \\
0,55\end{array}$ & $\begin{array}{l}\text { Касари } \\
\text { Касари } \\
\text { Вигала } \\
\text { Энге } \\
\text { Вяндра } \\
\text { Сауга } \\
\text { Навести } \\
\text { Леммийыги } \\
\text { Кыпу } \\
\text { Мустйыги } \\
\text { Ахья }\end{array}$ & $\begin{array}{l}\text { Тээнусе } \\
\text { Касари } \\
\text { Рапла } \\
\text { Ядивере } \\
\text { Кийса } \\
\text { Эльби } \\
\text { Аэсоо } \\
\text { Сандра } \\
\text { Римму } \\
\text { Конувере } \\
\text { Коорвере }\end{array}$ & $\begin{array}{r}10,1 \\
9,8 \\
10,8 \\
10,0 \\
10,0 \\
10,4 \\
10,0 \\
9,6 \\
9,4 \\
8,3 \\
8,6\end{array}$ & $\begin{array}{l}0,57 \\
0,56 \\
0,61 \\
0,57 \\
0,57 \\
0,59 \\
0,57 \\
0,55 \\
0,54 \\
0,48 \\
0,50\end{array}$ \\
\hline
\end{tabular}

Институт мелиорации и освоения осушенных земель Академии наук Эстонской ССР

Поступила в редакцию 17 XII 1954

\section{ЛИТЕРАТУРА}

1. С. Н. К р и ц к и й и М. Ф. М ен ке ль, Гидрологические основы речной гидротехники, Изд. АН СССР, М.-Л., 1950.

2. А. В. Ог и в в ки й, Гидрология суши, Сельхозгиз, М., 1952.

3. Д. Л. Соколовски й, Речной сток (Методы исследований и расчетов), Гидрометеоиздат, Л., 1952.

4. Д. Л. Соколо в с к й, Водные ресурсы рек промышленного Урала и методика их расчета, Гидрометеоиздат, Свердловск-Москва, 1943. 